\title{
Russia as a great power, 1815-2007
}

\author{
Iver B. Neumann \\ Norwegian Institute of International Affairs, PO Box 8159 DEP, Oslo NO 0033, Norway. \\ E-mail: iver.Neumann@nupi.no
}

Russia's quest for the status of great power within the confines of the state system has been an ongoing concern since the time of Peter. After the Napoleonic Wars, Russia thought it had acquired great power status, only to discover that, after the Crimean War, it had either never been firmly obtained or it had been lost. Since the fall of the Soviet Union, the issue has once again dominated the foreign policy debate. Part 1 presents the two traditional ways of defining great power (Weberian vs Durkhiemian), and suggests that, in order to account fully for the lack of recognition by established great powers, we need to add a third, concerning governance. The inspiration for this move I take from Foucault's work on the emergence of governmentality. Russia's lack of social power to have its regime type accepted as being on a par with European ones is the key problem hampering Russia's quest for recognition. Drawing on extant historical studies, part 2 presents empirical evidence that this factor was present and remains so in European representations of Russia. I conclude that, as long as Russia's rationality of government deviates from present-day hegemonic neo-liberal models by favouring direct state rule rather than indirect governance, the West will not recognize Russia as a fully fledged great power.

Journal of International Relations and Development (2008) 11, 128-151. doi:10.1057/jird.2008.7

Keywords: Europe; governmentality; great power; Russia; states; system

\section{Introduction}

From early contacts between Muscovy and the Holy Roman Empire through the rapid increase in contact during and following Peter the Great's reign and finally during the Soviet period, Russia has tried to be recognized by the leading European powers as their equal. ${ }^{1}$ This quest has taken on an importance that places it squarely at the centre of Russian identity politics. Indeed, Russian nationalism congealed historically around this very issue. When, in the early 1990s, leading politicians wrote newspaper articles about how they did not want to live in a 'banana republic' and when Russian and European politicians point to data in a wide range of fields listing Russia on a par with smaller powers, the message lends its power from the tacit assumption that a small-power Russia is an impossibility. ${ }^{2}$ Russia has to be a great power, 
or it will be nothing. Indeed, this is an explicit, self-referential axiom in Russian identity politics, and has been so for a very long time. To quote the Russian Foreign Minister from 100 years ago, Aleksandr P. Izvol'sky, 'decline to the level of a second class power [... and] become an Asiatic state [...] would be a major catastrophe for Russia' (Lieven 1983: 6).

The persistence of the theme and the intensity of its presence in Russian identity politics suggests that Russia's quest for recognition as a great power has not been a successful one. This is because, if an identity claim is successful, it forms part of the horizon of the political debate rather than its substance. Recognition of Russia as a great power can only be given by great powers that are firmly established as such. Historically, that means the European powers to the West of Russia. It follows that if we want to account for Russia's feeling of non-recognition, then we need to give an account of what the criteria for great powerhood have been, and then discuss where Russia has been found wanting. Note that the main focus must then fall on how Russian state-building was represented by contemporary great powers.

Great power discourse has been dominated by a school of thought that has highlighted material power resources and the ability to project power, particularly military power. The problem with this so-called realist account is that, in the periods 1815-1848 and, arguably, also 1957-1991, Russia has met the criteria noted by realists, but full formal and informal recognition has nonetheless failed to emerge. This suggests that the realist account has failed to recognize the full gamut of preconditions for recognition. Historically, there does exist another and competing account of greatness, which fastens on moral greatness. It highlights how Russia, when judged by the standards of moral purpose shared by extant great powers, has consistently come up a bit short. The problem with this account is that, as an explicitly ethical account, it plays itself out in the somewhat disembodied sphere of ideas in the political realm. The scope of validity offered by this account is the ideational alone. This is too narrow a scope to account for a problematique, which is an aspect of the political as such. I begin my argument by discussing the classical loci of these two positions in social theory. ${ }^{3} \mathrm{I}$ then suggest that we may forge a third and better account of Russia's recognition problem by approaching the problem from the angle of governance. Like the realist account, such an account takes cognizance of the materiality of the discourse which is left out by the moral account, and like the moral account, it is predicated on the intersubjective character of recognition, a factor which is left out by the realist account. In the main part of the paper, I apply the three accounts to some of the extant literature in an attempt to demonstrate that the governance-oriented account gives us the fuller understanding of Russia's non-recognition problem. I conclude by spelling out some corollaries. 


\section{Two Reading of Great Powers in Social Theory and an Underlying Factor}

Categorization is an unavoidable and dynamic part of taking action. If the Durkheimians are right that high/low and large/small are organizing devices of social reality on a par with time, space, cause and effect, then any social system, the states system included, will and must have some kind of categorization of entities according to these principles. (A categorization of equality will confirm this rule by being a way of categorizing that explicitly negates it). The questions are on what grounds, with what effects. Since its inception as an academic discipline, International Relations has carried on a debate about the practical as well as the analytical importance of according some powers the status of being great powers. This debate was preceded by and has been paralleled by debates in the disciplines of international law and history.

In his major work, the immediate precursor of IR realists Max Weber defined a great power in the following way: 'Nowadays one usually refers to those polities that appear to be the bearers of power prestige as the "Great Powers", (Weber 1991: 161). ${ }^{4}$ Prestige - Machtprestige - is the crux of the matter. To Weber, it is not specific to the states system, but rather a general 'irrational element' towards which every polity strives. At a minimum, in order to be a great power, a power has to think of itself in terms of being great, of having an historical task. In the states system, Weber insists that great powerhood is in practice relational: it means 'the glory [Ehre] of power over other communities' (Weber 1991: 160). ${ }^{5}$

To Weber, as to Vattel and Ranke before him, prestige is obviously tied in with military and economic factors. The comparatively superior strength and the mutually recognized spheres of influence that are constitutive of great powers may, therefore, be seen as what we would now call structural characteristics of the states system. In their eyes, these are characteristics of the social organization of states. However, in a slightly different context, Weber also noted that 'There is a close connection between the prestige of culture and the prestige of power' (Weber 1991: 448, n6). The reason why this emerges as a move of crucial difference is that, when used in this way, terms involving comparison emerge as explicitly intersubjective. Their meanings are then seen to depend on a game of negotiation by two or more agents. Seeing a great power as intersubjectively constituted by the actors of a system is a very different thing from seeing it as structurally constituted by the states system. Since Weber's usage was ostensibly in line with the meaning commonly ascribed to the term great power in the early decades of the 20th century, however, this seems to have gone unnoticed at the time.

In a lecture course on the state that he offered in 1913 that was only published in its entirety in 1950, the other key sociologist of the early 20th century, Emile Durkheim, set out his views on great powers (Durkheim 1950/ 
1992). Durkheim saw the emergence of the modern state as emanating from a small cadre (historically, the King and his advisers). This state is one thing, the society that eventually comes to rule another: "the State is nothing if it is not an organ distinct from the rest of society. If the State is everywhere, it is nowhere. The State comes into existence by a process of concentration that detaches a certain group of individuals from the collective mass' (1950/1992: 82). In the beginning, Durkheim held, this state does not have many ties to society: 'it is above all the agent of external relations, the agent for the acquisition of territory and the organ of diplomacy' (1950/1992: 85). The more the state grows, however, the denser its interface with society, and the more democratic it becomes. Durkheim famously describes this as an organic process, whereby the head grows an ever more finely honed cybernetic system with which to operate its societal body. ${ }^{6} \mathrm{He}$ insists that this process is characteristic of the modern state from the 17th century onwards. Here we have a clear-cut criterion for gauging which states are 'great' and which are not. Drawing on the concept of pride, which seems close to Weber's prestige, Durkheim argues that

As long as there are States, so there will be national pride, and nothing can be more warranted. But societies can have their pride, not in being the greatest or the wealthiest, but in being the most just, the best organized and in possessing the best moral constitution (Durkheim 1950/1992: 75).

Where Weber acknowledges the importance of cultural factors but ultimately treats them as a factor shaping power, Durkheim makes specific use of a moral way of comparing states by denigrating 'certain democracies' that do not understand that the state must take the lead in economic matters, leaving this important sphere of social life to the market. Inasmuch as democracy to Durkheim is a sign of maturity, and inasmuch as his criticism is clearly directed against Britain (and, at least by way of collateral damage, the United States), the implication of this way of phrasing the question is to leave Durkheim's native France as the paradigmatic great power (1950/1992: 86-94). To Durkheim, the key is that states may or may not be great in a moral sense. Note, however, that Durkheim also makes an intriguing hint at how governance (regime type and efficiency) is a key factor of great powerhood.

In social theory, there is a bifurcation in how great powers are conceptualized. $^{7}$ The question asked is what are great powers. The answer is, on the one hand, they are simply greater in terms of the relative resources they can bring to bear on interaction with other states, and, on the other hand, they are prestigious due to some superior moral quality.

Whence this prestige? In both IR and social theory classifications, a distinction is made between quantity and quality. Prestige is something more than overwhelming force, and it is to do with morals, that is, with which social 
practices that constitute the political entity in question, and how these are assessed on ethical grounds. The concept that has been used for this overall phenomenon in the European tradition for the last two centuries is civilization. In the IR literature, civilization has generally been a concern to people discussing the existence of a formal standard of civilization in international law (e.g. Gong 1984). In social theory, it has been a concern of historical philosophy (e.g. Elias 1994). Seemingly, there is little if any extant theorizing about how civilization is tied up with great power prestige. I would like to suggest, however, that there exists a rich literature on the question under a different heading, namely that of regime type. From the earliest RussianEuropean contacts, Russia's system of rule was seen as being despotic (Neumann 1997: 65-86; Poe 2000). Throughout the 19th and 20th century, it was seen as authoritarian or even totalitarian (Gleason 1951; Groh 1961). Parallel to the discourse on great powers - and I have in mind both the state conversations and the analytics of state conversations here - there exists a rich and continuous discourse on the key political question of how Russia orders the relationship between the one and the many. In keeping with the idea that the international and the domestic are two distinct realms of politics, these two discourses have seemingly been disconnected. I would suggest, however, that the discourse of great powers has been embedded in the wider discourse of regime type. The distinction made in the analytics of state conversations has blinded us as analysts to the fact that the state conversations themselves turned not only on the general questions of despotism and civilization, but on the specific question of regime type. I will give examples of this below. Here we have an underlying factor that may account for the unexplained aspects of great powerhood as described by realist and moral accounts. A power may also count as great by governing in a way that is deemed exemplary by others.

Indeed, Durkheim touches on the questions of rule and governance in his treatment of great powers without making it his explicit focus. He argues, however, that greatness may be secured simply by setting an example, that is, by making moves that are purely ideational in character. I disagree. As demonstrated by contemporary Sweden, it is fully possible to share a system's moral purpose without being amongst that system's great powers. ${ }^{8}$ It is a necessary, but not sufficient, prerequisite that the power in question has the material resources to socialize others into its system of governance. Once that is accomplished, however, the afterglow of superior governance may outlast superiority in resources. Consider the case of the East Roman or Byzantine empire's last centuries. Oikonomides (1992: 74) holds that the most striking point about its foreign policy was that

in the fourteenth century as well as the thirteenth, for all its increasing weakness, Byzantium acted as if it was still a great power of the past. 
Moreover - and this is even more interesting — other powers seemed to ignore reality and to accord the Byzantine ruler a special status: he was seen as the emperor par excellence, the head of a state that used to be a basic fixed point of European politics over past centuries.

It is Oikonomides who ignores reality here, not the polities in the vicinity of the Byzantine empire. Those entities owned the legal systems that constituted them and increased their capacity to rule to the Byzantines. ${ }^{9}$ To stay in the metaphorical lingo of the day, Byzantium was the father house, and the state households (or, in the Greek of the Byzantines, the economies) of the other polities were the houses of the sons or, rarely, of the brothers. The sons looked to their father with respect even in his dotage. ${ }^{10}$

The process whereby the European states system spread worldwide was not as clear cut. Beginning with Turkey and Russia, European rulers came up against powers that claimed superiority or parity for their own and had different governing structures. Such claims clashed with the European system for classification of these other polities, which explicitly focused on their system of government. Only those peoples whose political system closely resembled the European one were classified as civilized. Peoples with other large-scale systems were generally categorized as barbarians, and people who had few or no specifically political institutions as savages. As José de Acosta wrote in 1590 in a book about the new world, 'It is a proven fact that barbarian peoples show their barbarity most clearly in their government and manner of ruling, for the more closely men approach to reason the more humane and less arrogant is their government' (quoted in Bowden, forthcoming). The topic receives its most elaborate theoretical form in Hegel, and by the 19th century, it was firmly ensconced in international law. For example, Westlake (1914: 143) writes about it at great length under the heading 'Government the International Test of Civilisation'.

I find Michel Foucault's discussion of how the rationality of government changed in Europe following the emergence of a (new type of) society from the 16th century onwards to be particularly enlightening in order to specify where this 'standard of civilization' came from and how it informed the ranking of political powers. To Foucault, the emergence of society as a not immediately transparent layer which comes between the sovereign and his subjects eventually led Western European states to complement direct rule by indirect rule. Such a move has as its discursive prerequisite a move away from thinking about subjects as part of a household headed by the sovereign, towards thinking of them as a partially self-organized productive group. It has as its material prerequisite that the state may draw on an adequate and varied enough amount of resources to pull this off. Foucault views the emergence of liberalism and its imperative that the state should always ask how 
it may rule less (i.e. less directly) as an historical answer to the emergence of society. Note that governing less simply means governing less directly; real existing liberal states have increased the size of their state apparatuses and the gamut of their instruments of governing for over two hundred years now.

Indirect rule by the state is dependent on inculcating a certain sense of responsibility for their own lives amongst the citizenry, so that they may govern themselves (along the lines indirectly laid down in discourse). Foucault refers to such 'conduct of conduct' as governmentality. To grasp the meaning and import of 'governmentality' as a form of power, it is useful to contrast it with that of sovereignty. Foucault identifies a historically significant transformation occurring from the sixteenth century onwards in which what he terms the 'art of government' emerged to form a practice that was separate and partly autonomous from the principle and practice of sovereignty (Foucault 1978/1991). 'In contrast to sovereignty', Foucault (1978/1991: 100) notes, 'government has as its purpose not the act of government itself, but the welfare of the population, the improvement of its conditions, the increase of its wealth, longevity, health etc.' Thus, for Foucault, government is defined in terms of the 'conduct of conducts', involving a range of techniques and practices, performed by different actors, aimed to shape, guide, and direct individuals' and groups' behaviour and actions in particular directions (Foucault 1978/1991: 102-03, 1979/2000: 341). The central elements of government as a form of power is captured in the following distinction made between the workings of sovereignty and the workings of government:

with sovereignty the instrument that allowed it to achieve its aims - that is to say, obedience to the laws - was the law itself: law and sovereignty were absolutely inseparable. ... [W]ith government it is a question not of imposing law on men, but of disposing things; that is to say, of employing tactics rather than laws, and even of using laws themselves as tactics - to arrange things in such a way that, through a certain number of means, such and such ends may be achieved (Foucault 1978/1991: 95).

The concepts of 'disposing things' and 'employing tactics' are an essential feature of government as a form of power. In contrast to both sovereignty and discipline, which are the two other key modes of power theorized by Foucault, government takes the freedom and agency of those that are governed as both and end and a means for governing.

With the introduction of autocracy, the sovereign's right to reign is transcendentally based on a mandate from God himself. The exertion of power took shape as two types of practice: first as raison d'état (or prudencia mixta, see Oestreich 1982: 48) and second as what in French and English was actually called police, in German Policey (later Polizei). ${ }^{11}$ Police was a concept that was 
commonly used when referring to different types of statutory provisions that various power centres produced in early modern times:

Police had the connotation of administration in the broadest sense, that is, institutional means and procedures necessary to secure peaceful and orderly existence for the population of the land (that is, territory). Police in this sense, obviously a sense derived directly from polis, was apparently first used in Burgundy (hence the original German spelling policie and policey) in the late fifteenth century, from where it passed to the Hapsburg chanceries (Raeff 1983: 5).

The first known use in German is from Würzburg in 1476, but the most frequent use was under the wars of religion at the 14th century (Oestreich 1982: 155-65). The sovereign became sovereign among other reasons because he slowly succeeded in obtaining exclusive rights to produce such statutory provisions. The meaning of the police-concept thus changed and became a general and contemporary description of the sovereign's ideal order based on the reason of state. "The concept of "police" covered the authority which the ruler arrogated to himself to issue commands and prohibitions. The new structure of command and obedience contributed to a further break-up of feudal society,' writes Oestreich (1982: 157). The proclaimed goal was for police to cover as many aspects of human life as possible, in what was called der wohlgeordnete Polizeistaat - the well-ordered police state. Foucault suggests, and this is crucial to our undertaking, that ties between states meant that good police was a question that concerned Europe in its entirety, and not just one's own state. As he puts it,

One can only effectively maintain the balance and equilibrium in Europe insofar as each state has a good police that allows it to develop its own forces [...] In the end there will be imbalance if within the European equilibrium there is a state, not my state, with bad police. Consequently, one must see to it that there is good police, even in other states. European equilibrium begins to function as a sort of inter-state police or as right. European equilibrium gives the set of states the right to see to it that there is good police in every state (Foucault 2007: 314-15).

The new rationality of governing which Foucault refers to as governmentality posed a problem for Russia from the very start. First, it was a rationality different from the one informing sovereignty, and so a potential threat. Secondly, a prerequisite for the state's being able to use this rationality was that the state could draw on a varied slate of resources. The Russian state, whose system of government was less effective and less efficient than that of (other) 17th and 18th century European states, was at a relative disadvantage. As a result, the move in the direction of pervasive 'police' was 
inefficient in Russia. So was the move to indirect rule that was increasingly in evidence in France, Britain, the Netherlands, Sweden and Denmark, and at a later stage and often in weaker forms in France, the German states and indeed in all states to the West of Russia. Given that regime type was considered to be a key criterion when gauging how heavily a certain polity weighed in the scales of civilization, the resulting widening discrepancy between Russia and the great powers was of key importance for how the latter weighed the former in general, and Russia's claim to being a great power in particular.

A whole swathe of historians has discussed these discrepancies under various headings such as the lack of a Russian liberal tradition and the failure of Russian reforms. What I want to do here is to move these insights into a realm where they have been previously absent, namely IR debates about Russia's standing as a great power. I hypothesize that the lack of social power to have these governing structures accepted may account for Russia's problems in not being recognized as a great power. Weber's and Durkheim's approaches each take us part of the way, but adding a governmentality perspective takes us even further. Let us pair up what we may call the realist, the moral and the governmental accounts of great powerhood with a series of examples of European assessments of Russia as a great power over the last two hundred years in order to see which account that may give us a better understanding of the issue.

\section{Europeans Assessing Russia}

On Weber's realist criteria - material resources and the ability to project power - there is no doubt that Russia was a great power by the end of the 18th century. Similarly, on Durkheim's moral criteria - setting an example for how a state should be in the world - the socialization into the states system would appear to be strong enough for Russia to qualify. ${ }^{12}$ There remained no doubt about its Christian credentials, the principle of legitimacy was the same as in the other powers, dynastic intermarriages had become common. How, then, should we account for the ubiquitous European complaints about Russia's lack of civility and the continuing doubt about the extent to which it should be considered as part of Europe? For Russia was still not seen as weighing heavily on the scales of civilization. An example is David Hume's complaint that 'the two most civilized nations, the English and French, should be in decline; and the barbarians, the Goths and the Vandals of Germany and Russia, should be in power and renown (quoted in Horn 1945: 18-19). Variants of this complaint were heard in other forms and in other arenas. In 1804, the French ambassador Hédouville complained to his Foreign Minister Talleyrand that 'There is no other foreign court where the diplomatic corps is less 
informed on political dispositions and proceedings than here' (quoted in Grimsted 1969: 19).

Turning towards the issue of governance allows us to highlight two factors. First, regarded as a police state, Russia was less successful than others. ${ }^{13}$ The capacity for state action was less efficient and more limited. Hamilton and Langhorne (1995: 74) highlights how Peter's reforms also embraced the state apparatus. A 'new college of foreign affairs was established, and unlike some of Tsar Peter's reforms survived a period of near chaos after his death and grew to have 261 members at the accession of Catherine the Great in 1762. The college had a president, vice-president and two chancery councillors at its establishment, and during the eighteenth century steadily lost its responsibilities for internal provincial (also Central Asian) administration, ecclesiastical administration, for tax gathering and for the postal system, which was separated in 1782' (comp. Meissner 1956). The result was that, as late as at the eve of the nineteenth century, 'Compared to the smaller and more efficient foreign offices of many other European powers, the Russian ministry counted on its rolls an extraordinary large number of officials, from those of higher ranks to clerks, codifiers, translators, and copyists. The exact number of men functioning at a given time is almost impossible to ascertain because the rolls listed many persons who rarely or never served' (Grimsted 1969: 26).

Secondly, during the 18th Century, European societies emerged and states changed their way of handling societies from being one of direct rule to one of indirect governance. In Europe, this period saw the gradual emergence of liberal forms of governing that replaced that of the police state, and society gradually replaced territory as the object of reference for governing. While this system weakened the further east from Britain one moved, liberalism, understood as concrete social practice, firmed its grip. Russia eventually had to take cognizance of the change. In summing up Catherine the Great's reign, Bruce Lincoln places the emphasis on how one cause of her social policy was that Russia's 'status as a Great Power' imposed an imperative for civil peace, which again imposed heightened efficiency in the Russian administration. He then adds another factor which added to this imposition, namely that a number of young Russian bureaucrats were impressed by European Enlightenment thinking, and thought that Russia had to conform to Enlightenment ideals of how a civilized polity should be governed. As Lincoln sums up the point,

the pre-modern military and fiscal concerns of Muscovite Tsars confirmed poorly to the image of a Great Power that their sovereigns hoped to project. To be sure, Russia's military needs continued greater than ever, but, as a Great Power, she also must exhibit some proper concern for her citizens (Lincoln 1982: 3, also 175). 
To paraphrase, a new ethos of what governing a state entailed was setting a new standard not only for what a state had to be in order to be considered well-ordered, but also for which states should be considered great powers. Liberalism formulated an imperative whereby letting go of the state's direct control of society was becoming a necessity not only for reasons of efficiency (producing a surplus that could feed state need, including a military capacity), but also and more fundamentally for reasons of conforming to a new Europe-wide standard of governance (the need to appear 'normal'). Given 19th century European thought's penchant for conceptualizing world history in terms of stages taking place in the same order and leading to the same goal, the lack of normality was read more specifically as a slow rate of civilizational development. ${ }^{14}$ Russia was a laggard in introducing what was considered a civilized form of government, and this made it inferior. ${ }^{15}$

On the strength of moral criteria, after the Napoleonic wars, Russia was the great power par excellence. At Vienna in 1815, Russia's role as great power was institutionalized. At this time, for the specific purposes of managing the system of states, being the military arbiter of Europe proved sufficient. Only five powers were given the right to have ambassadors extraordinary and plenipotentiary, and Russia was among them. We note, however, that Russia experienced trouble with maintaining its greatpower credentials throughout what Eric Hobsbawm calls the 'long 19th century' (1789-1917), and that this may be accounted for by the factor of governance. Indeed, Vattel's definition, that a great power should be able to hold its own against any constellation of other powers, was put to the test after the Vienna settlement, when all the other great powers allied against Russia in the quadruple alliance and Russia held its own with ease. In relative terms, Russia's strength weakened throughout the 19th century. Realism cannot account for this, but an account highlighting the factor of governance can. System of government was at the heart of Russia's increasing inability to match the growth in prosperity found (elsewhere) in Europe.

A moral reading of Russia's tenuous standing as a great power throughout the 19th century would highlight how, as the principle of legitimacy shifted towards popular sovereignty, Russia led the rearguard action on the behalf of kingly sovereignty. Such an account is, of course, apposite. When there was a shift in Britain and France's position on what should be the constitutive principles of international society, Russia's response was to insist on the role of God and the heavenly mandate for kingly rule. What continued to tie Europe's monarchs together, tsar Alexander argued in 1815, was that they were brothers in Christ (Palmer 1974). His proposed Holy Alliance was clearly and explicitly embedded in such a discursive universe. As seen both by the formal and 
informal reactions to it, however, these arguments had lost not only their obviousness, but also some of their persuasiveness. Russia's inability to rally the other great powers who constituted the Congress of Europe behind a program of policing Europe against regimes based on popular sovereignty demonstrates how the discrepancy on the principle of legitimacy translated into inability to act in concert. The result was continued questioning of Russia's standing as a European or even a civilized nation. Grimsted (1969: 3) is right when she argues that

Russia's stature as a great European power reached its zenith because the economic, social and political developments which were to transform the European continent in the next hundred years had not, by 1800, separated Russia from Western Europe to the extent that would be so evident in the Crimean War at mid-century.

As a more liberal type of governing took hold domestically as well as between states and established itself as 'normal', Russia once again became a laggard. Where governance between states is concerned, The Congress of Vienna had marked a breakthrough in international governance. It stabilized state boundaries between European states, and insulated Europe from extraEuropean rivalries. Much in the same way as Adam Smith had conceived of political measures as preconditions for economies to thrive, international agreement demarcated specific areas (understood as state-contained societies) for states to govern. This changed the meaning of what it meant to be a great power. As Paul Schroeder puts it, the general principles of the Concert of Europe 'protected the rights, interests, and equal status of the great powers above all, but they also committed these powers to the performance of certain duties connected with those rights - respect for treaties, noninterference in other states' internal affairs, willingness to participate in the Concert's decisions and actions, and a general observance of legality and restraint in their international actions' (Schroeder 1986: 12-13). It became harder and less legitimate to compensate for bad governance with territorial expansion in Europe. In the 18th century, the three partitions of Poland and the resulting territorial aggrandizement of Russia, particularly after the third division, had a certain aggrandizing effect on Russia's standing as a great power. By contrast, Russia's imperial policy in Poland, Finland etc. in the 19th century did not have such an effect, but was rather detrimental to its standing. The explanation for this is to be found in the increasing importance assigned to systems of government.

This is generally occluded by realist analyses, which often conclude that, in the period from the Vienna settlement to the Crimean War (1853-1856), Russia was not only secure in its great powerhood, but that it was even preponderant. For example, William Wohlforth (1999: 21 note 30) holds that the Concert of 
Europe as it operated in this period was 'based on a Russo-British cohegemony'. Paul Schroeder disagrees, pointing out

The common view that Russia enjoyed an enormous and growing power and prestige in Europe until the Crimean War broke the bubble is a great exaggeration. After 1815, Russia never was the arbiter of Europe or exercised the dominant influence in Germany that Catherine II or Paul I had enjoyed for a time, and the young Alexander I had aspired to (Schroeder 1986: 10).

The point here is that, underlying not only the growing gap in relative resources but also the gap in principle of legitimacy was a difference in governance. At the heart of Russia's troubles as a great power was its unwillingness and inability to change from a rationality of direct rule to a rationality of indirect governmentality. Again, consider Lincoln's argument that

If Russia was to meet the challenge posed by the rapidly industrializing West, she, in turn, had to find some way to achieve greater administrative efficiency and instil into her middle- and upper-level officials a measure of support for change. Russia's bureaucrats had to become responsive to the needs of the nation they served, and some means had to be found to enable those few who were well informed about complex social and economic issues to gain input into the tsarist policy-making process (Lincoln 1982: 6).

Lincoln's book painstakingly traces how this process unfolded in the middle of the 19th century to culminate in the emancipation of the serfs in 1861 and leading to sweeping judicial reforms directly and explicitly inspired by European models (esp. Lincoln 1982: 200). It is of key interest, however, that Russia's autocratic order put a clear limit to how such moves could be taken. If all power should in theory emanate from the Tsar, bureaucracy had to maintain the principle of direct control from above. Therefore, Russia's politicians could not act independently. Neither was there any way in which they could function as aggregators of societal interests apart from the tsar, and so any economic strengthening of the emerging middle class could not find any direct political expressions. 'As a result, just when the new social and economic groups that comprised the middle class were eroding the power of absolutism in the West, it was strengthened in Russia' (Lincoln 1982: 7).

There is broad consensus in the historical literature about the logic and importance of this process. In terms of state-society relations, the problem was that Russia simply did not have the social agents necessary to mediate between the state and the population at large. This meant that a necessary precondition for indirect rule was lacking. Given the absence of self/government amongst the subjects, if the state decided to ease direct rule, there was an immediate 
danger that anarchy would ensue. Therefore, moves to indirect rule, which would entail the easing of direct rule, were precluded. As Geyer (1977: 27-8) puts it

As a result of the new attitudes forced on the government, the reform period witnessed the first flowering of political journalism in Russia. [...] A common thread to all the criticism was opposition to the bureaucratic machinery of the state and demands for self-government and 'openness' (glasnost'). No consensus existed, however, on the question of who should be responsible for self-government in the districts and provinces: aristocrats 'born' to mediate between the ruler and his people? owners of private property in their capacity as the most respectable group of citizens? the educated classes as the preceptors of the people and defenders of democratic rights?

The state was not able to put any of these social groups to good use, which meant that it was basically stuck with the state apparatus. Within this apparatus, however, the regime once again ran into the elite social forces, which it was not able to harness for indirect rule. The regime's lack of ability to deploy its own apparatus effectively meant that direct rule was inefficient as well. To draw on Dave Alan Rich's (1998: 29) formulation, 'autocracy's constructed dynastic myth left little room for state professionals. Partnership with the rising ranks of experts who filled the central bureaucracy - and sharing of authority with them — were beyond its defining tropes.' Rich's example is the Russian General Staff. The military leadership's response to the reforms of the 1860s was to embark on professionalization. This succeeded in setting up a solid planning operation, but having it implemented proved difficult, since the tsar and his immediate family sat at the top of the military hierarchy from which they were able to stall the process. Having failed to circumvent the royal family, the General Staff simply gave up. As summarized by Rich (1998: 19):

...civilian political leaders, who had sought unification of policy in the Council of Ministers after 1905, ultimately found themselves hobbled by habits of insularity and by the supreme power, Tsar Nicholas II, who thought government his personal possession. Professional bureaucrats, the experts whose authority might have insinuated interministerial political unity, instead settled into parochialism, and none more so than the technicians of the Russian general staff. In the end, professionals were not the potential savoirs of autocracy and empire but virtual guarantors of their demise. ${ }^{16}$

As did his predecessors, Nicholas operated according to a rationality of government where the tsar was supposed to be the head of the household. Etymologically, we may even trace this in the Russian term for state, 
gosudarstvo, which translates loosely as the holdings of the lord. The unwillingness to let the sovereign's documents count for more than the sovereign's whim, that is, the unwillingness to subsume leadership under the law, meant that Western-style bureaucratization was held back from the top. After the assassination of Alexander II in 1881, his son and successor passed a Statute of exceptional measures which gave one such body, the secret policy, a free run on the sovereign's subjects. Zuckerman (1996: 13) concludes from a careful reading that 'the political police by the mid-1880s already operated beyond the control of the regular bureaucracy'. Since these measures remained in force until the October revolution, one may indeed describe Russia as a 'police state' in these years, but in a very different meaning from what 16th and 17 th century Europeans meant by 'police'.

Note that the bureaucracy tended to experience the delegation of power to ad hoc organs like the secret police and those organs' subsequent tendency to ignore the bureaucracy's instructions as a direct hampering not only of their own power, but also of the effectiveness of the state. This may be seen, for example, in the internal fight between the ministry of Finance and the ministry of the Interior over the development of labour movements. Up until 1903, when the so-called starosta (elder) law allowing the choice of elders from amongst the workers to play a role as spokesmen was established, forming anything approaching even a proto-union had been illegal. The new law followed a failed attempt by Sergey Zubatov, head of Moscow's secret police, to construct police-controlled worker organizations. McDaniel (1988: 65) comments that

The Zubatov experiment was the closest the Russian state ever came to a corporatist policy of creating and coopting dependent organizations, a strategy that achieved notable successes from the standpoint of the authorities in numerous other countries.

In Russia, however, the state was too aloof, the industrialists too weak and the workers too unused to the give and take that is necessary for industrial relations to work for the Zubatov experiment to be successful. Again, the preconditions for indirect rule simply were not present. McDaniel stresses how autocracy's choice not to accommodate social groups was a self-conscious one, quoting the soon-to-become Internal Minister hailing in 1902 'the complete independence of our government' (Sipyagin quoted in McDaniel 1988: 58). Note, however, that he also traces the impulse to study indirectly in this debate, for one of the express reasons why the Ministry of Finance wanted the starosta law in the first place was

to reduce the role of the police in the factories as much as possible. The law had its origins in the request of factory inspectors that they be allowed 
'to summon worker deputies and talk with them' before the police intervened. The Ministry of Internal Affairs, they claimed, did not sufficiently recognize this duty of the factory inspectorate, and unfortunately all disorders were dealt with by the police (McDaniel 1988: 90-1).

Of course, the spokesman for indirect rule, the Minister of Finance, was a liberal (Witte), whereas the Internal Minister who was inclined towards direct rule was a conservative. The conservative was right in his assumption that indirect rule would undermine the regime, and so he won the debate. We may conclude that at least some Russian bureaucrats as well as its few liberal politicians shared the assessment of European statesmen where the weakness of the Russian state was concerned. They did not, however, draw the same conclusion, or at least not in the same degree, namely that Russia did not meet the standard of civilization necessary to pass muster as a great power.

For our purposes, where the key is to spell out the different rationalities of rule and government between Russia and other European regimes, these analyses may be generalized in ways that give them analytical purchase even today. Consider, for example, Moshe Lewin's (1987) reading of Russia's inability to reform. Throughout the nineteenth and twentieth centuries, Lewin argues, the Russian state would perceive the situation to be one where Russia was losing out to Western competitors due to the relative lack of productivity of its enterprises. In reaction, the Russian (or Soviet) state would ease its direct control of enterprises, and encourage them to increase their own initiative. The enterprises would go ahead and do so, and at some point, their very success would generate demands on the state (in the form of pressure for different systems and degrees of taxation, for new legislation, for a say in decisionmaking, etc.) The state would not consider itself to be able to answer these demands without systems-wide change, and would respond by putting an end to reforms. Leaning on the governmentality perspective, this process is easily defined as one of the state refusing to accept a change away from logic of direct rule towards a logic of indirect governance. Society is not allowed to exist as an institutional and hence non-transparent reality. As seen from Europe, Russia held on to an outmoded and inefficient mode of state power, which made it appear anything but great. The result was, to quote Lincoln once again, that

By 1856, the political ideologies of the West stood in unflinching, hostile array against those very precepts and institutions of autocracy that Alexander II was sworn to defend and to which the enlightened bureaucrats were committed by necessity and conviction. Europeans unhesitatingly saw in Russian autocracy the personification of that tyranny they had fought to destroy in the revolutions of 1789, 1830, and 1848, and the survival of autocracy only strengthened some of them in their opposition to Russia's claims for recognition as a European power (Lincoln 1982: 175). 
Arguably, the tsarist empire's resistance to Western pressure for a change towards liberal governance cost it its life for it alienated the regime from every single emerging social group and zapped its military strength when it was most needed. Debate about whether the balance of power should be conceived as a balance of capabilities or a balance of threats has its specific counterpart in the debate about whether great powerhood should be assessed in terms of material or perceptual indicators. For example, William Wohlforth (1987) demonstrates how, in the decade leading up to the First World War, policy makers were led astray by their trust in numbers, which made them grossly overestimate Russia's power. Interestingly, the power that held that power to be the most modest was Russia itself. Since Wohlforth operates within the problematique of order, he rests content with demonstrating the discrepancy. ${ }^{17} \mathrm{~A}$ focus on governance suggests that the more intimate Russian knowledge of its weakness in this regard explains its modesty in overall assessment of its great powerhood. As Wohlforth himself demonstrates, furthermore, it was exactly the inability of foreign observers to appreciate the full importance of the state's tenuous hold on society for its international standing and survival that led them astray. Within Russia itself, however, there were key people who fully grasped the problem. Consider Grand Duke Constantine Nikolaevich's lament that 'we cannot deceive ourselves any longer $[\ldots]$ we are both weaker and poorer than the first-class powers, and furthermore poorer not only in material but also in mental resources, especially in matters of administration' (quoted in Lieven 1983: 21). What the Grand Duke did not note, however, was that having someone like himself on top was exactly one of the things that made it impossible for tsarist Russia to match the administrative systems of the 'firstclass powers'.

When, in its final months, the tsar turned to the ambassadors of Russia's allies, who were also representatives of the most liberal states in the system, the stock answer was that the tsar should broaden the popular basis of his government. Despite the odds, he vehemently refused. After a short socialist interregnum, a communist regime was installed. In terms of resource base, the Soviet state quickly matched the level of resources once possessed by tsarist Russia. Realists may account for this by pointing to Soviet disinterest in managing the system, and a Durkheimian may account for it by pointing to the different principle of legitimacy on which the communists operated. By the same tokens, they may produce complementary accounts of how the Soviet Union regained its great power status after it emerged victorious in the Second World War. But, how may they account for the repeated relevance of the view, held by Western leaders like Winston Churchill, that the Russian leaders were barbarians, and the matching uneasiness of the Soviet leaders towards what they at some level obviously considered their more highly cultured counterparts? Consider an example from a period which, according to a realist 
account, has the Soviet Union play the role of one of the world's two superpowers. In his memoirs, Nikita Khrushchev compared himself to a heroine of a popular play from the 1930s, Lyubov' Yarovaya, where little Dun'ka undertakes a trip to Europe. The expression 'as Dun'ka in Europe' passed into everyday language, translating as something like 'as a country bumpkin in the big city'. Khrushchev wrote that

Dun'ka's travel to Europe was of consequence and went to show that that we could deal with international matters even without Stalin's orders. To use a metaphor, in foreign policy we had thrown away the boy's shorts and donned the long trousers of the adult. [...] We felt our power (Khrushchev 1993: 78).

Maybe so, but how to account for the insecurity obvious in the need to spell out how one feels from the leader of a state that perceived itself and was perceived by the other powers in the system as having the military might of a great power? Fulfilling the criterion of having enough economic strength to uphold a military might that was great in relative terms appears as a necessary, but insufficient criterion of great powerhood here. From Grand Duke Constantine to Khrushchev and beyond, we see a continuing Russian fear of being seen as inferior by (other) European powers. And indeed, beginning in the late 1980s, post-Soviet leaders themselves began to identify the root cause of their uneasiness vis-à-vis the West in civilizational terms. One of the key slogans of the perestroika period was the need to 'rejoin civilization', a slogan that logically implied that the Soviet path had somehow led Russians away from it (Neumann 2005). With the fall of communism, for the next ten to fifteen years, the official Russian self-understanding of the Soviet past came to blame a mistaken system of governance for the lingering problems in what was frequently referred to as the civilized world. There was a tentative turn to European liberal models of government. During this period, the understanding of Russia as inferior was often shared by Russian leaders themselves.

During the 18th and 19th centuries, the Russian elite adopted a number of European social practices (marriage patterns, military procurement and deployment, diplomacy), and partook in the management of the states system in ways that were explicitly associated with great powers (having ambassadors plenipotentiary, being a guarantor power, participating in conferences, gaining a droit de regard). Still, doubt lingered in European capitals - and in some degree in Russia itself - about its role as a great power. Realists, which treat great powerhood as a matter of having and being able to project material and especially military power, may account for why Russia was increasingly recognized, but not for the lingering doubt. A moral account, which takes intersubjectivity seriously and stresses the degree in which a power accepts confluence of norms, may account for some of the doubt. It cannot, however, 
account for the lingering doubt in periods when Russia largely adhered to international norms. I have suggested that a governancy-based account, which focuses on regime types and their representations by other powers, can. Mine is a power-based and socially grounded account. As noted in the introduction, whereas this reading is something new in social theory and IR, a non-theorized prototype of it is fairly prominent in the work of Russian historians. ${ }^{18}$ For example, Bruce Lincoln (1982) remarks on Catherine the Great's reign how one cause of her social policy was that Russia's status as a Great Power' imposed an imperative for civil peace and a need to 'exhibit some proper concern for her citizens' (Lincoln 1982: 3, cf. 175).

\section{Conclusion}

With the coming to power of Vladimir Putin in 2000, the official Russian line continued to be that Russia remained a great power, but one that now sought recognition in terms of democracy and market economy. Ostensibly, this is a liberal model. It is, however, only superficially so. In a work on the 1905 reforms in Russia, Weber once characterized the new system of government as Scheinkonstitutionalismus - fake constitutionalism. Putin's use of liberal slogans such as the rule of law etc. are equally lacking in seriousness and practical purchase. To quote an analyst who singles this out as a key development, Viatcheslav Morozov (2007: 18) writes that

As the liberal reforms of the social security system failed, the government tended to opt for paternalistic solutions, such as the measures aimed at raising nativity rates, demonstrating that the stronger state is better in providing security to the people. Foreign policy came to be dominated by the idea of establishing Russia as a strong and independent player on the global stage - here, as in domestic politics, autonomy became an end in itself.

The thinking about government that is promulgated by slogans such as managed democracy, sovereign democracy, etc. is predicated on the idea that a strong state may serve as the guarantee of the system of governance. The problem is that the model of governance that Russia pledges to implement here runs directly against a key liberal trend, where the question is how the state may govern less. Putin's view of what a state should do is the exact opposite of liberal. It focuses on how the Russian state should rule in a direct fashion and up front, not govern indirectly and from afar. It sees society as something to be managed, not as something that must by necessity be given a certain leeway. It sees law as one of the instruments of the executive, not as a check on it. It sees even human rights as something that is guaranteed by the state, not as something that pertains to individuals because they are human beings. What 
this means is that Russia is once again evolving a rationality of government that has firm precedents in Western Europe but that has, at the time of Russia's adopting it, been left behind by West European states themselves. The Russian state is once again opting for direct rule.

In the 19th century, in the wake of the French revolution and the Napoleonic Wars, Russia was also faced with the dilemma of choosing to follow the Western lead of giving society more leeway and govern by indirect means, or to maintain its policy of direct rule. It decided to maintain an ancien régime while other European powers went for modernization. In the 20th century, in the wake of the First World War, Russia again parted ways with other European powers by trying to implement a socialist future while the others hung on to their bourgeois present. In the 21st century, Europe seems to be set on a course of integration. If Russia wants to repeat its formal pattern, it should hang on to its sovereign present while others forge ahead. The problem, however, is that this will no doubt entail a whole swathe of interesting challenges of incompatibility. Russia's problem with being recognized as a Great Power is a social one. At its root is the question of relations between state and society. As seen from Europe, a Great Power cannot have state/society relations that are too different from those that at any one given time dominate European politics. In the final analysis, in order to achieve and maintain the status of a Great Power, social compatibility is needed. When, to quote a paradigmatic voice from Putin's Russia, Natal'ya Narochnitskaya argues that Russia 'haunts Europe, which, having built its 'paradise on earth', remains apprehensive of our magnitude and our capacity to withstand all challenges', she neatly sums up the problem. For it is not enough to parade what Russia itself considers 'strength' in order to be recognized as a great power (quoted in Prozorov 2006: 42). ${ }^{19}$ What is needed is to demonstrate strength and power that is recognized as being of a sort which makes its wielder a great power by the light of the firmly ensconced great powers. If that is what it takes to be recognized as a great power, then Russia under Putin is playing the wrong game.

With Russia's choice under Putin, the societal differences that have historically existed between Western European powers and Russia and those that are inextricably linked to the system of governance, are still with us. Examples include ownership, freedom of contract, judiciary and penal practices, health administration and a whole range of other practices. In a words, if, as I have argued, great powerhood depends not only on having material resources and being able to project military power, then Russia has now once again chosen a course that will thwart its ambitions to be recognized as a great power on a par with leading European powers and, even more crucially in terms of power, the United States. It is not just Russia's material base (Russia's gross domestic product being one-thirteenth of that of the US, less than half that of United Kingdom's and a third of Germany's) that goes to 
show that Russia's membership of the G-8 is by courtesy only. Russia's standing as one of five permanent members of the UN Security Council is yet another formal institutional feather in Russia's cap, but it cannot cover up the lack of a social base for great powerhood. The inability to project power in a degree sufficient to please a realist together with the unwillingness to play according to the moral rules laid down by extant great powers and the unwillingness to change the state to approximate a rationality of governing by indirect means stand in the way of it being able to earn the recognition of other states that it seemingly strives so hard to achieve. The very policy that is ostensibly forged to 'make Russia strong again' is predicated on an understanding of strength that is partial and dated. In a world where the liberal standard of civilization which played such a crucial role in the international relations of the 19th century is coming back in force, Russia will not be counted as a fully fledged great power for decades yet.

\section{Acknowledgements}

Thanks are due to the Institute for Human Sciences in Vienna, where, as December Guest in 2002, I commenced work on this piece. Thanks also to Kristian Gerner, Hiski Haukkala, Ted Hopf, Pål Kolstø, Ole Jacob Sending, Alexander Sergunin, Shogo Suzuki and William Wolforth for comments on earlier drafts.

\section{Notes}

1 I treat the early centuries in Neumann (2007), which covers the period before the one treated here.

2 See, for example, Aleksandr Rutskoy in Komsomolskaya Pravda (17 January, 1992).

3 For a discussion of how they play themselves out within the narrower confines of the discipline of International Relations, see Neumann (2007).

4 'Jene politischen Gemeinschaften, welche jeweilig als Träger des Machtprestiges auftreten, pflegt man heute 'Grossmächte' zu nennen (Weber 1976: 521).

5 '...praktisch: die Ehre der Macht über andere gebilde.' (Weber 1976: 520).

6 The state is said to be 'a brain which controls the function of inter-relationship; but the visceral functions, the functions of the vegetative life or what corresponds to them, are subject to no regulative action. Let us imagine what would happen to the functions of heart, lungs, stomach and so on, if they were free like this of all discipline [...] Just such a spectacle is presented by nations where there are no regulative organs of economic life' (Durkheim 1950/1992: 30).

$7 \mathrm{We}$ find the same positions and the same fault lines in the IR literature, cf. Neumann (2007).

8 The title of a book written at the behest of the Swedish state, From Great Power to Welfare State: 300 Years of Swedish Development (Samuelsson 1968), is therefore highly suggestive in more ways than one.

9 Rule, not govern; I use governmentality here for the rationality that characterizes distinctively modern forms of political rule or government. The Byzantines did not have the means by which to govern individuals from afar in any detail. See Foucault (1991). 
10 While this example has somewhat limited analytical purchase, it is important because, without Byzantium as a living exemplar in their midst, the regular patterns of interactions broke down, and Byzantium's neighbours quickly came to shed the legal structures that they had adopted from Byzantium. The system that these polities had made up evaporated, and the grounds on which the polities constituting it could be ranked in relation to one another evaporated with the system.

11 These two concepts were actually used rather interchangeably at that time. Giovanni Botero's Della ragion di stato from 1589 was translated to German seven years later as Johannis Boteri Gründlicher Berich von Anordnung gutter Polizeien und Regiments: auch Fürsten und Herren standes (Oestreich 1982: 161, n 15).

12 It is of the essence for understanding the full extent of Russia's socialization to add a governance point, namely that the opponents of Westernization slowly but surely also started to acquire a frame of reference and to borrow their arguments from Western models. For example, the Russian conservative rallying around the well-ordered police state was a rallying around a German model. Arguments for maintaining an oligarchic constitutionalism are actually another case in point: 'In eighteenth-century Russia the meaning of the word constitution was different from the one that the reformist movement would give it in the nineteenth century. The term meant, in fact, political system, implying the strengthening of the autocratic regime' (Medushevskii 2001: 45).

13 But note that Medushevskii maintains that Peter's reforms, themselves inspired by Sweden and other Western states, 'in its turn became the stereotype or principal reform model for Russia and some West European countries in the era of Enlightened Absolutism (the administrative reforms of Frederick the Great in Prussia, Joseph II in Austria, Catherine the Great in Russia, Struense[e]'s attempts at reform in Denmark). But Peter's model of modernisation was most influential in the Orient' (Medushevskii 2001: 46). For an extended comparison of Russia and Prussia as police states, see Raeff (1983).

14 Note that the thinking in civilizational terms was not specific to liberalism, but was representative of the entire 19th century.

15 Comp. Neumann (2004). Where the economic basis for great powerhood is concerned, there is a sharp division of opinion between historians regarding the eighteenth century. The traditional view is that Russia was lagging steadily behind. The revisionist view sees this as a 'myth' (Bagger 1993: 66), stresses Russia's economic modernization and export surplus, and points out that domestic stagnation only set in in the 1830s. To the revisionists, the traditionalist view is a case of illegitimately projecting the undoubted backwardness of the nineteenth century onto the previous one. This debate shall not concern us further here. We simply note consensus has it that, by the standards of the 18th century, Russia was not considered by the other powers to be efficient.

16 Amongst the examples he offers is the way Nicholas stopped a general staff debate over combat doctrine in 1912 with the words: 'Military doctrine consists of doing everything which I order' (quoted in Rich 1998: 221). Rich also notes how the military was not able to 'govern from afar', which is another defining trait of governmentality: 'War planners, like their counterparts throughout the state structure, found themselves endlessly carping at subordinates in the provinces to get on with their work. The achievements of the few military, scientific, and technical experts underscore the narrowness of the Russian empire's basis for rationalization and regularization' (Rich 1998: 17).

17 Wohlforth later took cognizance of extra-rational factors. In an article about the US's standing as a great power, a footnote reads: 'I focus on material elements of power mainly because current scholarly debates place a premium on making clear distrinctions between ideas and material forces' (Wohlforth 1999: 7, n 10). Interestingly, analysis in terms of governmentality, which dedifferentiates material and ideational factors, would reach broadly similar conclusions regarding the present-day US as does Wohlforth. 
18 See Malia (1999), Mosse (1996) and Hosking (2002).

19 Prozorov (2006) rightly highlights the self-exclusion of Russia from Europe, and rightly stresses how galling Russians find it that the recognition game seems always to be played on somebody else's terms. The subaltern's conscience is an unhappy conscience.

\section{References}

Bagger, Hans (1993) 'The Role of the Baltic in Russian Foreign Policy', in Hugh Ragsdale, ed., Imperial Russian Foreign Policy, 36-72, Cambridge, NY: Cambridge University Press.

Durkheim, Emile (1950/1992) Professional Ethics and Civic Morals, London: Routledge.

Elias, Norbert (1994) The Civilizing Process, Oxford: Blackwell.

Foucault, Michel (1978/1991) 'Governmentality', in Graham Burchell, Colin Gordon and Peter Miller, eds, The Foucault Effect, 87-104, Chicago: Chicago University Press.

Foucault, Michel (1979/2000) 'Omnes et Singulatum', in James D. Faubion, ed., Power: Essential works of Foucault 1954-1984, Vol. 3, 298-325, London: Penguin.

Foucault, Michel (2007) Security, Territory, Population: Lectures at the Collège de France 1977-1978, Houndmills: Palgrave.

Geyer, Dietrich (1987) Russian Imperialism: The Interaction of Domestic and Foreign Policy, 1860-1914, Oxford: Berg.

Gleason, John Howes (1951) The Genesis of Russophobia in Great Britain: A Study of The Interaction of Policy and Opinion, Cambridge, MA: Harvard University Press.

Gong, Gerrit W. (1984) The Standard of 'Civilization' in International Society, Oxford: Oxford University Press.

Grimsted, Patricia Kennedy (1969) The Foreign Ministers of Alexander I: Political Attitudes and the Conduct of Russian Diplomacy 1801-1825, Berkeley, CA: University of California Press.

Groh, Dieter (1961) Russland und das Selbstverständnis Europas: Ein Beitrag zur Europäischen Geistesgeschichte, Neuwied: Hermann Luchterhand.

Hamilton, Keith and Richard Langhorne (1995) The Practice of Diplomacy: Its Evolution, Theory and Administration, London: Routledge.

Horn, David Bayne (1945) British Public Opinion and the Partition of Poland, Edinburgh: Oliver and Boyd.

Hosking, Geoffrey (2002) Russia and the Russians: From Earliest Times to 2001, London: Penguin.

Khrushchev, Nikita (1993) 'Memuary', Voprosy istorii (8).

Lewin, Moshe (1989) The Gorbachev Phenomenon: A Historical Interpretation, London: Radius.

Lieven, D. C. B. (1983) Russia and the Origins of the First World War, Houndmills: Macmillan.

Lincoln, W. Bruce (1982) In the Vanguard of Reform: Russia's Enlightened Bureaucrats, 1825-1861, DeKalb, IL: Northern Illinois University Press.

Malia, Martin (1999) Russia Under Western Eyes: From the Bronze Horseman to the Lenin Mausoleum, Cambridge, MA: Harvard University Press.

McDaniel, Tim (1988) Autocracy, Capitalism, and Revolution in Russia, Berkeley, CA: University of California Press.

Medushevskii, Andres (2001) 'Administrative Reforms in the Russian Empire: Western Models and Russian Implementation', in Lindsay Hughes, ed., Peter the Great and the West, 39-50, London: Palgrave.

Meissner, Boris (1956) 'Die zaristische diplomatie, A. Der Gesandtschafts-Prikaz (Posolskij Prikaz)', Jahrbucher für Geschichte Osteuropas, Neue Folge 4: 237-45.

Morozov, Viatcheslav (2007) 'Russia and the West: Dividing Europe, Constructing Each Other', paper presented at the annual conference of the International Studies Association, Chicago, IL, 28 February-3 March 2007. 
Mosse, Werwer E. (1996) An Economic History of Russia 1856-1914, London: I. B. Tauris.

Neumann, Iver B. (1997) Uses of the Other: 'The East' in European Identity Formation, Minneapolis, MN: University of Minnesota Press.

Neumann, Iver B. (2004) Ispol'zovanie 'Drugogo': Obrazy Vostoka v formirovanii evropeyskikh identichnostey, Moscow: Novoe izdatel'stvo.

Neumann, Iver B. (2005) 'Russia as a Great Power', in Jakob Hedenskog, Vilhelm Konnander, Bertil Nygren, Ingmar Oldberg and Christer Pursiainen, eds, Russia as a Great Power: Dimensions of Security Under Putin, London: Routledge.

Neumann, Iver B. (2007, forthcoming) 'Russia's Quest for Recognition as a Great Power, 14891815', in Theodore Hopf, ed., Russia's European Choices, Houndsmills: Palgrave.

Oestreich, Gerhard (1982) in H.G. Koenigsberger and Brigitta Oestreich, eds, Neostoicism and the Early Modern State, Cambridge: Cambridge University Press.

Oikonomides, Nicolas (1992) 'Byzantine Diplomacy, A. D. 1204-1453: Means and Ends', in Jonathan Shepard and Simon Franklin, eds, Byzantine Diplomacy: Papers from the Twenty-fourth Spring Symposium of Byzantine Studies, Cambridge, March 1990, 73-88, Aldershot: Variorum.

Palmer, Alan (1974) Alexander I: Tsar of War and Peace, London: Weidenfeld \& Nicolson.

Poe, Marshall T. (2000) 'A People Born to Slavery': Russia in Early European Ethnography, 14761748, Ithaca, NY: Cornell University Press.

Prozorov, Sergei (2006) Understanding Conflict between Russia and the EU: The Limits of Integration, Houndmills: Palgrave.

Raeff, Marc (1983) The Well-Ordered Police State: Social and Institutional Change Through Law in the Germanies and Russia, 1600-1800, Ithaca, NY: Yale University Press.

Rich, Dave Alan (1998) The Tsar's Colonels: Professionalism, Strategy, and Subversion in Late Imperial Russia, Cambridge, MA: Harvard University Press.

Samuelsson, Kurt (1968) From Great Power to Welfare State: 300 Years of Swedish Development, London: Allen \& Unwin.

Schroeder, Paul W. (1986) 'The 19th-Century International System: Changes in the Structure', World Politics 34(1): 1-26.

Weber, Max (1921/1976) Wirtschaft und Gesellschaft: Grundriss der verstehenden Soziologie. Studienausgabe, fifth ed., Tübingen: J.C.B. Mohr.

Weber, Max ([1948] 1991) From Max Weber: Essays in Sociology, London: Routledge.

Westlake, John (1914) The Collected Papers of John Westlake on Public International Law, Oppenheim, Lassa, ed., Cambridge: Cambridge University Press.

Wohlforth, William C. (1987) 'The Perception of Power: Russia in the Pre-1914 Balance', World Politics 34(3): 353-81.

Wohlforth, William C. (1999) 'The Stability of a Unipolar World', International Security 24(1): $5-41$.

Zuckerman, Frederic S. (1996) The Tsarist Secret Police in Russian Society, 1880-1917, London: Macmillan.

\section{About the Author}

Iver B. Neumann is a Professor of Russian Studies at the University of Oslo and a Research Professor at the Norwegian Institute of International Affairs. $\mathrm{He}$ is currently working on issues of diplomacy and global governance. His most recent book (co-edited with Daniel Nexon) is Harry Potter and International Relations (Rowman \& Littlefield, 2006). A Russian version of his book Uses of the Other: 'The East' in European Identity Formation (University of Minneapolis Press, 1999) appeared in 2004. 